DOI https://doi.org/10.36059/978-966-397-113-1/237-261

\title{
PROBLEMS OF ORGANIZED CRIME PREVENTION
}

\section{Miniailo N. Ye.}

\section{INTRODUCTION}

In an unstable socio-political, financial and economic situation in the country crime poses a serious threat to social development. It has become one of the negative factors that affects the effectiveness of public authorities and government, undermines the stability of the law and order, protection of rights, freedoms and legitimate interests of citizens, violates the principles of democracy and social justice.

Organized crime in Ukraine is a rather multifaceted phenomenon with general common grounds that are inherent in any organized crime of any country. Nevertheless, it definitely possesses its features received as a result of the historical development of Ukraine, the peculiarities due to its territorial position on the geographical map of the world, the ideological and cultural values of our society. To identify and shape such features one should consider the main historical stages of the formation of Ukrainian organized crime.

In 2011 the President of Ukraine approved the Concept of state policy in the field of fighting organized crime, scheduled by 2017, which states that it is a significant factor in increasing social tension and destabilization of social relations, the emergence of deformation in the field of economic activity, slowing down the pace of economic development of the state. This Concept points to the importance, urgency and necessity of integrated scientific research and analysis, groundwork in the field of the latest scientific development and proposals for reducing its.

Ukraine still has an approach to understanding organized crime through the quantitative expression of the totality of crimes committed in connection with the creation and operation of organized crime groups. At the same time, by improving the state fundamentals of counteraction to organized crime, our state must proceed from the depth of its essence and the diversity of manifestations. An important analysis in this area is the analysis of international standards for the definition of organized crime 
and the practice of various European countries to disclose the content of this concept.

Since the late 1990s and early 2000s organized crime in Ukraine has a new stage in its development conditioned by a number of prerequisites. At this time the effectiveness of the law-enforcement system is significantly weakened, facilitated by lengthy and unsystematic reforms of various law enforcement agencies, often with the omission of its priorities counteracting organized crime itself. During a given period in a society the negative consequences of organized crime activity are acutely felt by every person.

The current crime situation in the state indicates the need to improve measures aimed at neutralizing the influence of factors that predetermine the development of organized crime. Organized crime is characterized by a high level of latency, which is indirectly, first and foremost, corrupted by representatives of the state and the judiciary. Understanding of the real situation of crime and organized crime in particular, is necessary for the introduction of adequate legislative measures to counteract them.

Organized crime tries to penetrate the most important spheres of life of society and the state - to the authorities and management, to establish control over financial and industrial groups, separate enterprises, subjects of entrepreneurial activity, lobby their own interests in legislative bodies and public administration. The priority directions of activity of organized groups and criminal organizations are changing, the purpose of which is to receive significant income.

The importance of the formation of detailed statistical data of the results of the fight against organized crime in all its manifestations will be facilitated by its law enforcement agencies in its real assessment in the dynamics. It is the reflection of the real state of organized crime that will improve the system of counteraction to this phenomenon, and will not diminish the role of those law enforcement agencies that are directly fighting its expression, will contribute to an analysis of the quality of their work and the search for methods to improve their effectiveness.

\section{Theoretical and legal foundations of crime prevention}

Different terms are used in national and foreign legal practice, as well as in legal literature, to designate crime prevention activities and take measures aimed at reducing it, such as «warning», «prevention», «fight», 
«control», «counteraction», «war», «termination», etc. Each of these concepts causes scientific discussion and is not evaluated as sufficiently defined. We believe that each of them has different content. The most commonly used to explain the nature of such activity in the modern Ukrainian criminological literature are the terms «prevention» and «counteraction». But they are given a different content load. Some researchers of this problem believe that the term «counteraction» in the broad context encompasses prevention and serves to determine the overall impact on crime. It is believed that the concept of «struggle», «counteraction» belongs to the class of generalized, which reproduce the general essence, consisting in the implementation of resistance and does not reveal the essence of prevention.

Based on the foregoing, we believe that the terms «struggle», "war» to a greater extent determine the repressive approach in the field of counteracting crime by the state and is a more narrow area of counteraction, many authors believe that the terms «fight», «war» with crime does not reveal the essence of the anti-criminal efforts of society and the state. Such activities should be defined by the concept of «counteraction to crime». It covers several spheres of influence on crime: general social, criminological, criminal, judicial, etc.

Regarding the use of the term «crime control», which is common in the western countries, especially in the United States, it should be noted that this term did not get used to domestic criminology. But some scientists use it in the sense of «counteraction».

Thus, crime prevention is a complex of socio-legal phenomenon and a concept that reflects the theory and practice of specific governmentmanagement activities and private initiatives aimed at preventing the commission of crimes, eliminating their causes and conditions, interrupting the offender. Activity or criminal act committed at different stages of their implementation, bringing the subjects of their commission to criminal liability and applying to them the measures of criminal law influence.

The structure of counteraction to crime contains two complexes (directions) of diverse efforts of society and the state, aimed at restraining crime within the socially permissible limits: 1) prevention of the commission of crimes; 2) response to crimes committed. 
The essence and content of each of the directions of crime prevention different researchers understand in their own way. It should be noted that the prevention of crimes is a complex of efforts aimed at eliminating the causes and conditions of the commission of specific criminal acts, so that the subject who intended to commit a crime, got rid of this intention, as well as to stop the crimes. The indicated direction of crime prevention in modern conditions is recognized as the main and more effective in comparison with others - the reaction to already committed crimes.

The reaction to the commited crimes is a complex of criminal legal reaction to criminal manifestations using criminalistic means of disclosure and investigation of crimes, the implementation of punishment and other means of influencing criminal behavior.

Crime prevention in the literal sense means the activity that prevents the commission of crimes. But the content of this activity should also include legal and forensic means of responding and committed crimes that could not be prevented. Thus, counteraction to crime involves the prevention of crimes and the state-legal reaction to their commission.

Prevention of the commission of crimes is an activity functional content and purpose of which is to interfere with the actions of determinants of crime and its manifestations, primarily the causes and conditions of the commission of a crime, by limiting, neutralizing, and, if possible, eliminating their actions, as well as in stopping started crimes.

Depending on the stage of prevention, the prevention is divided into: 1) the prophylaxis of the commission of crimes; 2 ) the prevention of the commission of crimes; 3 ) the cessation of the commission of crimes.

The prophylaxis of the commission of crimes in the criminological literature and in practice recognizes the purposeful activity on timely prevention of violations of any social norms, elimination of the causes that give rise to these violations. There are various directions of social prophylaxis: sanitary, technical, medical, veterinary, legal (prevention of offenses and crimes), etc. Legal prophylaxis includes: prophylaxis of disciplinary, administrative, civil and criminal offenses and crime prophylaxis (criminological, criminal, criminal, penitentiary).

A more narrow definition of the concept of «prevention» as a specific direction of a special-criminological warning consists of a set of measures aimed at separate groups and individuals who implement criminal intentions, contemplate the commission of crimes and are positively 
perceived as a criminal way of life, in order to discredit criminal behavior, to refuse criminal motivation and intent, or the continuation of criminal activity.

Crime prevention is a set of measures aimed at separate groups or specific individuals who commit criminal intentions, contemplate the commission of a crime; elimination of criminogenic factors that cause the formation of a criminal motive before the crime is committed.

The cessation of criminal expressions is defined as a set of measures aimed at preventing the completion of the crime.

Thus, the theory of counteraction and prevention of crime as a kind of social and preventive activity includes measures aimed at limiting the factors, causes and conditions of crime and bringing the perpetrators to criminal responsibility. It is an integral part of the subject of criminology and defines the main task of this science - theoretically to substantiate and develop proposals on combating crime.

Crime prevention is an active influence on its causes and conditions at various levels of social life. In criminology there are three levels of counteraction and prevention of crime: general social, specialcriminological and individual.

The general social level of counteraction of crime is a combination of economic, cultural, educational, ideological, organizational and managerial, legal, technical measures, usually of a long-term nature, which ensure the proper functioning and development of the existing system of social relations and are indirectly aimed at countering crime.

These measures are developed and implemented by state authorities and management not with the purpose of direct counteraction of crimes but with the aim of solving current and future tasks of socio-economic development of the state, elimination of contradictions in public life. But indirectly they are aimed at eliminating negative phenomena and processes in various spheres of public life, which determine crime as a consequence. With criminality they have predominantly correlation links. National counteraction of crime is based on the condition of timely solving of sharp social contradictions, since it is impossible to eliminate secondary phenomena without removing the main negative phenomena with which they are inextricably linked. And this is clearly traceable in the light of the economic and social reform that occurs inconsistently with the aggravation of global social contradictions in all spheres of public life. 
The special-crime level of counteraction of crime is an aggregate of complementary measures complementing each other, the content of which is the activity of state bodies, public organizations and citizens in the development and implementation of measures specifically aimed at identifying, eliminating and neutralizing the negative circumstances that make the commission crimes and prevention of crime at different stages of the development of criminal activity. Special-criminological counteraction of crime is a professional activity that requires the use of special knowledge and methods of criminology, special planning, forecasting and management activities. It consists of the following independent areas: elimination or neutralization of causes and conditions conducive to the commission of crimes (criminological prophylaxis); termination of offenses and crimes; correction of persons who committed a crime; prevention of relapse; medical and psychiatric prevention.

The specially-criminological direction of combating crime is a complex target, closely related to social prevention in the broad sense. In general, social prevention involves the use of various measures that impede the development of anti-social forms of behavior. It is based on the recommendations of most social, natural and technical sciences, and in its essence identical to the general social prevention of crime, including a set of measures of education, observation, legal influence and treatment.

In the development of special-criminological measures for the prevention of crime, criminology, of course, uses knowledge and recommendations from other areas of social prophylaxis. But they do it purposefully, in relation to specific criminal phenomena and processes. Measures of social prevention are oriented on the whole population and aimed at ensuring social health of society. Therefore, these measures of special-criminological crime prevention are only part of the complex measures of social prevention in society.

Thus, criminological prophylaxis is a combination of activities with its identification and elimination of national and subjective conditions that give rise to crime, and also contribute to the growth of specific crimes. Depending on the phenomena and processes these preventive measures are divided into: review, restriction, elimination, protection.

Prophylaxis of prevention covers the activities of various subjects, consists of a set of measures, techniques and methods aimed at preventing the emergence and spread of various criminal phenomena and processes. 
Prophylaxis of prevention contains a wide range of measures: socioeconomic, ideological, legal, social and hygienic (for example, maternal protection, measures aimed at creating conditions for the upbringing of children, moral formation of an individual, ensuring proper working conditions, leisure, control and permits, etc. )

Under the prophylaxis of restriction, the activity of the subjects of prophylaxis, is creating conditions that hinder the spread of criminogenic objects at certain levels of social life, the determination of certain types of crimes, the formation of typological features of different categories of criminals.

The main place in the prevention system of elimination, which is carried out mainly by law enforcement agencies, are measures: procedural (submission of the investigator, separate decision of the courts), operational (liquidation of «Malin» and drones); informational and criminological (analysis of the crime situation), administrative (removal of moonshops, weapons, etc.).

Prophylaxis of prevention is a set of measures aimed at increasing the level of protection and safety of material objects and individuals from criminal encroachments. It creates external barriers to encroach upon the values protected by society. Prophylaxis of protection is widely used in practice. These are technical means of protection, branding and individualization of objects, public awareness about means and methods of encroachment and protection (forensic, victimological prevention).

Measures of special-criminological prevention are quite diverse. By scale these measures are divided into: national, regional, local and individual. State-wide - these are measures aimed at eliminating criminal phenomena in the country as a whole. Their implementation is due to the goal of implementing a single criminological policy in the state. Regional - these are measures aimed at eliminating or neutralizing criminogenic phenomena in certain regions. Local - it measures on the scale of individual objects or microgroups (enterprise, family).

Individual - these are measures for specific individuals inclined to commit offenses and crimes. They apply to people for whom there is a reasonable assumption, a forecast and the legal basis that this person is likely to commit a crime. Individual crime prevention is the preventive action of state and non-state bodies to prevent a crime from being 
committed by a specific person from which it is most likely to be expected to commit a crime.

Consequently, the object of this activity is: behavior and lifestyle of individuals with a high probability of committing a crime; anti-social orientation; psychophysical features of individuals; unfavorable environmental conditions; other long-term negative circumstances that determine the crime situation.

To determine the range of people who need individual prevention it is necessary to have factual, legal and criminological grounds. The actual reasons are the presence of antisocial behavior with its real manifestations. The legal basis is the regulation of preventive activities by law. Criminological grounds should be understood as the high degree of probability of committing a crime by a particular person.

Directions of individual prevention of crimes are: measures of persuasion, social assistance and coercion. Measures of persuasion - a set of educational activities aimed at forming in the person abandonment of criminal behavior, criminal intent, anti-social installations. These are conversations, listening to lectures on legal topics, individual or collective patronage, participation in community activities. Social assistance measures are employment, improvement of living conditions, changing lifestyle, raising the level of education, obtaining a specialty, establishing useful contacts, etc. Compulsion involves adverse consequences for the person, physical, material and technical. For example, control over the conduct of convicts, administrative supervision, arrest and administrative detention, fines, cessation of vagrancy and begging and so on.

By nature special-criminological activities are subdivided into: socioeconomic; socio-demographic; ideological political cultural and educational; organizational and managerial; technical control-permit; legal; therapeutic and prophylactic.

Differentiation of special-criminological measures by subjects is carried out depending on the competence and functional capabilities of the subjects. By content the activity of each subject of prevention is determined by its functional responsibilities.

To subjects of counteraction and prevention of crime belong state bodies, officials, public organizations, social groups, separate citizens, having the corresponding competence, rights and duties, whose activity in accordance with the current legislation is aimed at the development and 
implementation of activities related with the prevention, detection, limitation and elimination of criminal phenomena and processes generating crime. These include:

- the bodies administering the system of special-criminological counteraction and prevention of crimes determine the main directions, measures, tasks, forms of counteraction and prevention, the criminological policy of the state, plan, direct, coordinate and control it (state authorities and administration, local self-government bodies, executive and regulatory bodies);

- state bodies that carry out special measures for countering and preventing crime, by virtue of their status, and this activity is assigned to their main tasks and functions (Ministry of Internal Affairs, SBU, prosecutor's office, courts, control bodies);

- bodies and organizations whose activities indirectly influence the prevention of crimes (general and economic management bodies, information, statistical, medical, educational, cultural-educational);

- public organizations, associations of citizens and individual citizens (trade unions, public guardians of order, parties, religious organizations).

Among the subjects of special-crime prevention are local authorities and their executive and regulatory bodies, competent to carry out organizational and managerial functions for the prevention of crime, to organize and coordinate the work of the entities of the crime prevention system, to monitor the implementation of the decisions taken in the subordinate territory. To increase counteraction of crime they can form both permanent and temporary bodies. Various public organizations, workers' groups, officials, individual citizens (consumer protection society, environmental movement, etc.) play an active role in preventing crimes.

Among the subjects for which special-criminological counteraction and prevention are the main function or one of the functions are lawenforcement bodies, their units and services. These are the bodies of internal affairs, state security, court, prosecutor's office, arbitration, services for minors, correctional labor colonies, and the system of controlling state bodies.

Common to them is that the function of counteraction and prevention of crimes is allocated in an independent direction of activity. The content 
of this function is to identify and eliminate criminal phenomena, prevent crime, prevent and stop crimes, identify and eliminate causes and conditions conducive to crime, prevent recidivism and control the implementation of measures to combat crime.

Individuals implement preventive measures both in the framework of fulfilling certain civic obligations (upbringing of children) and public order (party, trade union), and in the personal initiative of countering various crimes, signaling to the competent authorities about criminal phenomena and criminal objects, promote the activities of law enforcement bodies (public assistant district).

The close link between the specialized actors in combating crime and the family, the population and public organizations provides a fairly high effectiveness of preventive practices. Family, community, religious organizations, prevention groups, cossack organizations, foundations, movements and many other organizations of public control are engaged in educational preventive work. Suffice it to say that more than two hundred non-governmental organizations declared in their statutory documents the work on preventing and combating corruption and crime. All these subjects are able to solve the problems of early and post-criminal prevention.

As for individual citizens in the Constitution of Ukraine, other legislative acts (criminal, criminal procedure, administrative legislation) there are norms that establish the duty and legitimacy of actions of citizens in protecting the interests of the state, their own legitimate interests and rights, the rights of other citizens from criminal encroachments.

Important for a complete analysis of crime is its information and analytical support. It is based on the legal, organizational, technical and methodological basis of purposeful activities on the collection, processing, storage, use of information necessary for the effective functioning of the system of counteraction to crime.

It involves the availability of information on the state, dynamics and structure of crimes, the impact on crime of the socio-economic status of the state, the activities of crime prevention actors. It should be noted that it is necessary to obtain sufficiently complete information that would reproduce the real state of crime in the country and the factors that determine it. 
In the context of the formation of an effective counteraction of crime, latent crime (from the Latin word «latens»- hidden and invisible) is of great importance, which is a set of actually committed crimes that, due to various circumstances, have not been reflected in official criminal statistics. The negative social consequences of latent crime are as follows. Violation of one of the fundamental principles of social justice - the inevitability of punishment for the crime committed. The untimely occurrence of responsibility for the crime committed encourages the commission of new crimes, which creates favorable conditions for recurrent, professional crime and prolonged activity of organized crime groups. In the morally-psychological aspect, the high level of latent crime forms the legal nihilism of citizens, doubts about the effectiveness of law enforcement agencies and their capabilities in the protection of life, health, property and other benefits. Latent criminality also has a negative impact on the development of criminal law and criminological policies, strategies and tactics of counteracting crime, undermining measures of social policy of the state.

The level of latent crime depends on many socio-economic, psychological, organizational and managerial factors. Among the main ones are the following: 1) the nature and prevalence of circumstances in connection with which the crimes are concealed;2) the state of legal consciousness and social activity of the population, aimed at counteracting crime; 3 ) the types and methods of committing crimes, the nature of their gravity (more serious crimes less latent, less severe - more latent); 4) the activity of law enforcement agencies in detecting crimes and criteria for assessing their activities; 5) stability of the legislation and judicial practice; 6) observance of the rule of law by state bodies and officials.

Now, in the context of intensive integration processes in the world, all countries are interested in the possibility to compare and assess the statistical indicators of crime in a variety of ways. Unfortunately, the indicators of criminal statistics in most countries are not comparable for various reasons - objective and subjective. For objective reasons, first of all, various criminal-procedural forms of carrying out of inquiry, investigation and judicial consideration of criminal cases, as well as the procedure of accounting and methodology of calculation of indicators, can be attributed. 
To the subjective - the interest of individual power structures and political forces in certain quantitative characteristics of the criminal situation in the country at the moment, which is most clearly illustrated by statistical data. Very often, subjective factors are decisive at any stage of registration and consideration of criminal-law phenomena.

It is no coincidence that the problems of improving statistical accounting have been repeatedly discussed at various UN congresses dealing with crime prevention issues, which constantly emphasized that only on the basis of statistical data are possible in-depth comparisons of trends in the development of economic crime in different countries and regions of the world.

Detection of latent crimes is a difficult task but quite real. In law enforcement agencies latent crimes are detected through the use of operational measures. Criminology knows a number of indirect methods for detecting latent crime. The simplest of them are reduced to various types of polls by using anonymous questionnaires. The main methods of detecting the level of latency of crimes are: to identify the level of victimologization of the population; analysis of complaints, applications of citizens coming to law enforcement agencies; analysis of messages in mass media; analysis of documents, materials of inspection of controlling bodies; study of data of forensic medical examination, polyclinic, hospitals; expert estimation method; analysis of actions of individual people (building of a house, sale on the markets of stolen products); analysis of technical and economic indicators of enterprises (raw materials - output, shortages and their causes).

Criminal statistics in most countries are decentralized and do not have a clear structural system, as in our country. The second feature is due to the lack of a single methodology and system for collecting data on crimes. The third feature is that information about crimes is collected by many different organizations. A widespread system of private statistical bodies serving primarily private companies, and sometimes executing orders from state statistical bodies. The fourth feature is the availability of a large amount of statistical information, its unsystematic nature and inequality, which prevents state statistical bodies from verifying the authenticity of statistical data.

Criminal statistics of crime of each state reproduces the specific features of its criminal law, process, judicial system, therefore, when 
studying the indicators of international criminal statistics on crimes, one should first of all bear in mind the differences of criminal legislation. In some countries criminal offenses are subdivided into crimes, misdemeanors and offenses. In others - for crimes and offenses.

In the third one - on criminal acts which are prosecuted under the indictment or without such, etc. The range of acts that are defined as economic or property crimes, as well as committed by organized groups, varies considerably. There are features and in the legal definition of individual concepts: complicity, attempt to commit a crime, relapse, and many others. Significant difference in the definition of the composition of such crimes. It is also necessary to take into account the degree of activity of the police and the court in the detection of crimes, as well as criminalprocedural law and the organization of a system of counteracting crime in individual countries.

However, in spite of all these difficulties, the comparative and statistical study of crime on an international scale provides an opportunity to identify the main trends, the dynamics of this crime in the world, its structure and the peculiarities of regional manifestations. It is important to use for this an analysis of the size of the damage from the commission of crimes in different countries, materials of economic, demographic sociocultural statistics, etc.

\section{Counteraction of organized crime}

The emergence, existence, spread and reproduction of organized crime is primarily due to the aggravation of contradictions in the development of society during the period of market transformation. These contradictions are the main crime-causing factors that determine the existence and reproduction of organized crime. Factors that determine the occurrence and existence of organized crime can be divided into objective and subjective. Objectives include factors that are conditioned by socioeconomic features of the functioning of society. To subjective ones are those caused by the disadvantages of organizing the work of operational units to combat them.

Objective factors of the emergence and existence of organized criminal groups is the growth of property stratification of the population; complication of the crime situation in the conditions of crisis phenomena in the economy; increasing activity of the shadow economy; changes in 
the legal consciousness of most of the population; a simplified approach to the study and analysis of the development of organized crime; the absence of an effective legislative framework for the fight against organized crime.

Subjective factors are: reducing the role of preventive measures; organizational and tactical miscalculations in the field of organization and implementation of counteraction to crime; systematic rotation and fluidity of operational composition; shortcomings of the professional training of operatives; miscalculations in determining the main directions in the fight against crime, low quality of operational overlap; low-quality work on operational accounting; unsatisfactory state of organization of interaction of operational units with investigators and supervisory bodies; disregarding the peculiarities of regional conditions; low level of control over the way of life and criminal activity of leaders of criminal formations and their active members; absence of offensive in the fight against organized crime; underestimating the professionalization and consolidation of criminal activity; disadvantages of informational and analytical work.

By the content they can be classified into economic, political, social, moral, psychological, legal and organizational and managerial factors of the existence, spread and reproduction of organized crime. Economic factors include: a systemic crisis in the economy, miscalculations in the strategy of privatization of state property, an economically unjustified full liberalization of prices, weak control of the state and society by the activity of individual economic entities, especially large monopoly enterprises, banking institutions, active activity of fictitious enterprises, high level of shadow economy, opacity of most segments of the market, first of all, fuel and energy, agro-industrial, etc.

Today the shadow economy is, in fact, an extensive system of obtaining extra profits which has its own shadow leaders and the specialization of individual segments. According to experts, the amount of illegal shadow economy is more than 50\%. It is usually in the interests of the criminal oligarchic clans of Ukraine, and not in the interests of society and the state. Tens of millions of Ukrainian hryvnas, not controlled by the banking system, go through the shadow sector every day.

In itself, the phenomenon of a shadow economy is inherent in all economic systems without exception but more significant is its volume, 
that in case of exceeding certain limits becomes of large scale and extremely dangerously affects all spheres of public life, instigates the spread and reproduction of organized crime.

An important economic factor is the erroneousness of the chosen direction of economic reform, the implementation of which led to the formation of a system that, by its existence and peculiarities of manifestations, generates a significant number of negative criminal factors contributing to the further spread and reproduction of organized crime, in contrast to, conventionally speaking, «normal» market economy. Of course, the last also contains a number of objective prerequisites for the existence of organized crime. But in the presence of civilized market relations they have reliable barriers.

The political factors of the spread of organized crime should be considered the growth of the corruption of the state apparatus and the use of immoral and sometimes illegal methods in political activity, the influence of criminal oligarchic clans on the functioning of the political system as a whole and certain political institutions.

One of the main social factors should be social apathy of the population, despondency to positive changes. To confirm the state of social apathy, it is not even necessary to carry out special studies or provide empirical data, because every citizen of Ukraine, unfortunately, can observe this condition every day in everyday life. An over-the-top confirmation of this can be the almost complete lack of response from the public to such phenomena as unprecedented increase in utility tariffs, arbitrary power failure by energy generating companies of entire neighborhoods. In countries that, from the point of view of the majority of Ukraine's population, are considered democratic and civilized, such facts would inevitably lead to violent protests.

A significant social factor in the existence, spread and reproduction of organized crime is the sharp stratification of society into extremely poor and very rich, low living standards of most social strata. At the same time, a small percentage of people live at extremely high standards of consumption, characteristic of the most economically developed countries, with the apparent lack of the majority of the population to achieve this legitimate.

Another social factor should be called the threat of organized crime, not only traditionally criminal, but also other spheres of life. In foreign 
countries, such as the United States and Western Europe, organized crime controls only criminal activity such as drug trafficking, weapons, trafficking in human beings, car theft, and smuggling. For legal business, members of organized criminal groups attempt to penetrate only in order to legalize profits from criminal activities or gradually withdraw from criminal activity. Organized crime in Ukraine and in many post-Soviet countries not only penetrates into most legal areas of activity, but even controls them. At this time, it is difficult to name at least one area of life that would not be exposed to organized crime.

Under the moral and psychological factors should be understood first of all catastrophic decline in morality in society, the devaluation of spiritual values. Much of the population was struck by purely consumer psychology. Representatives of criminal oligarchic clans and corrupt officials who publicly demonstrate their disparaging attitude to the law and law enforcement agencies began to identify moral norms in society.

An important moral and psychological factor in the existence, distribution and reproduction of organized crime is the domination in the social consciousness of the cult of enrichment, profit over the minimum labor costs. In this case, the enrichment is cultivated as much as possible, by any means, at any cost. In addition, the marked cult of overproduct has led to the existence of economic disproportion in the form of priority mediation over production. To eliminate this factor, it is necessary to involve economists and develop and legislatively establish the limits of the profitability of goods and services, and review the criteria for determining their cost.

A significant moral and psychological factor is the preferential treatment of the population of the so-called mafia life style, a peculiar effect of accustoming the public consciousness to organized crime. The noted effect of addiction is potentially dangerous by the threat of total criminalization of public consciousness, which results in almost the justification of criminals, the romanticization of a criminal way of life, the formation of greater trust in criminals, than to the authorities.

Another moral and psychological factor is the establishment in the public consciousness of the stereotype of «social proximity» of the criminal element, which was formed as a result of prolonged propaganda of such «proximity» of the criminal element in the years of totalitarianism. It created a sympathetic attitude to it, infiltrates the 
subculture of the criminal environment into public consciousness on a threatening scale. This is also facilitated by the proliferation and production of works that magnify the image of the offender. He is depicted as such a savior knight and a wise philanthropist, an unjustly imprisoned defender of individual freedom, a vibrant, creative personality.

Among the moral and psychological factors should also be called the psychological proximity of the business environment to organized criminalistics. This is a logical consequence of their moral and psychological unity. It is conditioned by the existence in the Soviet times of criminal responsibility for private entrepreneurship, commercial mediation and other economic crimes, which are now recognized as socially useful activities. This made people who engaged in such activities as criminals, facilitated their involvement in the criminal system of public relations.

Among the legal factors of the spread and reproduction of organized crime can be called such as the imperfection of the criminal legal regulation of counteraction to organized crime; internal contradiction and inconsistency of the system of legislation, in particular economic and tax, and the unsatisfactory state of legislative regulation of certain spheres of activity, especially economic ones, including the imperfection of the provisions of certain legislative acts regulating crime counteraction; criminogenicity of some legislative acts, non-implementation of their criminological expertise, etc.

Organizational and managerial factors that determine the existence, distribution and reproduction of organized crime are manifested in improper control of the use of national wealth, unwarranted intervention of officials in economic activity, and the disadvantages of the entire economic mechanism.

The state of counteraction to organized crime negatively reflects the conditions of organizational and managerial nature, which deal with the shortcomings of law enforcement activities of law enforcement and other state bodies. Among them should be: administrative failures in the organization of operational and service activities of law enforcement agencies; liberalism when sentencing members of organized criminal groups; shortcomings of operational search work; insufficient level of coordination in the fight against organized crime between individual law 
enforcement agencies; inadequate logistical, resource and personnel support of units for combating organized crime.

It should also be noted that inconsistency of actions and departmental corporate law enforcement bodies. It is only possible to counteract this by means of a clear legislative definition of the competence of various agencies in the field of combating organized crime with a mandatory warning about the prohibition of its arbitrary redistribution at the level of various types of by-laws.

An important negative circumstance is the bureaucratization of special units for combating organized crime and, in general, the system of law enforcement agencies.

The problem of resource support for crime prevention, especially organized, remains extremely relevant. In today's situation, when law enforcement officers, especially the governing body, have to perform more different kinds of economic activities than direct functions of the office to ensure the minimum necessary existence and functioning of the law-enforcement system, the importance of this issue is still increasing. Savings on the allocation of funds to the needs of law enforcement agencies cost the state too much, cause budget losses and generate other social problems.

Low legal and social security of law enforcement officers, including special units for combating organized crime. Infinite attempts to save budget funds on the abolition of additional social guarantees to law enforcement officers lead to negative events such as staff turnover and social tensions in law enforcement agencies that can not have a positive impact on crime counteraction.

Corruption plays a special role in contributing to the existence, spread and restoration of organized crime. Its devastating impact is felt throughout the world. This is due to the fact that power and management powers represent a great temptation for those who are prone to unjust enrichment. This is used by organized crime, unlawfully approaching the bureaucracy. It should be emphasized that some civil servants themselves often go towards criminal elements, wanting to receive money or material benefits for their services.

The above list of the main factors that determine the existence, distribution and reproduction of organized crime, determines the nature and content of measures to counteract and prevent it. 
General social measures, as noted in the criminological literature, include a radical reorganization of the country's economy, aimed at making impossible the functioning of the shadow economy, the penetration of organized crime into the sphere of the legal economy, the improvement of tax legislation, the impossibility of financial-banking and foreign economic crime.

The strategy of combating organized crime in modern conditions is to implement long-term measures aimed at eliminating the causes and conditions of this negative phenomenon, simultaneously eliminating specific organized criminal groups and organizations and limiting the field of their activities. Reliable barriers should be placed on the penetration of organized crime into the authorities and authorities, law enforcement structures, and the economy. To implement such a strategy, it is necessary that the counteraction to organized crime has indeed become the object of targeted state policy, and not only used during election campaigns. Necessary real political will of state leaders and broad support for civil society.

An important area of counteraction should be the taking of decisive measures aimed at eradicating organized crime from the legal sector of the Ukrainian economy, combined with steps towards its deinstitutionalization. The activities of law enforcement agencies and special services of the state are able to substantially reduce the economic and financial base of organized crime, since the most effective way to dispose of organized criminal groups is to detect and distort cash flows that ensure their functioning.

At the same time, it is necessary to exercise much more determination in the case of seizure of property if there is a suspicion that it was obtained as a result of criminal activity. It is necessary to provide a real guarantee of the security of citizens who reported suspicions about the activities of organized criminal groups or the source of income.

In recent years, the problem of ensuring the principle of inevitability of the punishment of organized criminal groups is very relevant. While the level of organized crime's latency is high, and the disclosure of these crimes, on the contrary, is low and the punishment for their commissioning is purely symbolic, all special-criminological activities aimed at counteracting organized crime will yield insignificant results. 
The urgent task is also the moral improvement of society, raising the level of general culture and justice of the population.

Improving the legal framework is important for activating the work on counteraction to organized crime. This is constantly emphasized by scholars and practitioners. Such proposals do not mean at all that there are no criminal-law norms in the state that regulate criminal responsibility for crimes committed by organized criminal groups. They certainly were and are. It is about their improvement, the creation of an optimal criminallegal framework in modern conditions: an offensive, directed against members of organized criminal groups and factors that determine the commission of their crimes.

The counteraction to organized crime should also involve measures of a criminal-procedural nature that deal with the regulation of the procedure for investigating criminal cases concerning the crimes of members of organized groups and criminal organizations, trial, execution of sentences, improvement of the work of the investigating staff, etc.

An important reserve of counteraction to organized crime should be active cooperation of operational units of law enforcement with civil society organizations and individual citizens.

The state of modern organized crime and corruption at different levels of government and administration requires the use by law enforcement of new, more effective, special-criminological measures, methods and methods of counteraction. From society as a whole and from special units to combat organized crime, it is required to create an effective and high-quality system for combating organized crime. Only active and offensive actions using all the means provided by law, a wellbalanced and professionally competent organization of operational-search activities, interaction with investigative units, the prosecutor's office and the court will ensure the fulfillment of the tasks of counteraction to organized crime.

Among the special-criminological measures, special attention deserves the issue of coordination of efforts of state bodies for counteraction to organized crime. After the elimination of the Coordinating Committee on Combating Crime under the President of Ukraine, the National Security and Defense Council of Ukraine and the Prosecutor's Office of Ukraine carry out functions for coordinating this 
activity. However, it should be noted that the activities of these bodies lack decisiveness and offensive character.

It is worth taking the experience and technology of combating organized crime, tested in other states, in particular in the United States (the allocation of significant financial and human resources, the use of modern methods of electronic surveillance, the involvement of secret employees, gradual but steady and qualitative accumulation of evidence in the case, etc.).

It is also possible to use the positive experience of creating so-called regional and interregional «shock groups» as part of the staff of various law enforcement agencies. Such structures in the United States are created to investigate the activities of specific organized groups. The period of their activities is not regulated in advance, that is, they must work until they have solved their task of tactical and procedural nature.

In the conditions of globalization of the global economy, the criminogenic processes become global. They determine organized crime, which is becoming more aggressive, has long crossed the borders of national states and has a transnational character. It is entirely natural that organized crime has become a matter of serious concern to the international community.

Since the mid-1970s, at the UN level, and later in the Council of Europe, a number of international legal acts have been adopted that formulate strategic principles for combating organized crime. The most important of these are the UN Convention against Transnational Organized Crime of 15 November 2000 and its additional protocols: the Protocol to Prevent, Suppress and Punish Trafficking in Persons, Especially Women and Children; Protocol against the smuggling of migrants by land, sea and air; Convention on Laundering, Search, Seizure and Confiscation of the Proceeds from Crime, 8 November 1990, Council of Europe Convention on Laundering, Search, Seizure and Confiscation of the Proceeds from Crime and on the Financing of Terrorism of 16 May 2005, European Union Strategy for the beginning of the new millennium «Prevention and control of organized crime»; Framework Decision of the Council of the European Union on combating fraud and counterfeiting of non-cash means of payment, dated May 28, 2001, Framework Decision of the Council of the EU of June 13, 2002 «On the European Arrest Warrant and the Transfers of Persons between Member States» and others. 
Appropriate congresses, seminars on crime prevention and the treatment of offenders were held, in which issues of activation of counteraction to organized crime were raised. Such events were held in Havana (1990), Suzdal (October 1991), Palermo (2000).

A characteristic feature of international treaties in the field of counteraction to organized crime is a fairly wide range of States parties. For example, 168 states have joined the United Nations Convention on Narcotic Drugs, the OOEN Convention on Combating Illicit Traffic in Narcotic Drugs and Psychotropic Substances has exceeded 158. Ukraine has also concluded dozens of interstate, bilateral treaties on legal aid in criminal matters.

In order to successfully fight organized crime, joint efforts are needed to counteract criminal gangs across the European space, joint mobilization of law enforcement and judicial authorities, balanced implementation of measures and an integrated strategy that sets priorities and clear goals for the implementation of relevant action plans.

In the above mentioned international legal documents it is recognized as necessary:

- carry out intergovernmental cooperation in the field of counteraction to organized crime, exchange of information between law enforcement bodies about the activities of organized criminal groups;

- establish operational-technical cooperation in various spheres of counteraction to organized crime;

- expand advisory services in order to exchange experience and new achievements in the fight against organized crime;

- improve customs, passport and transport control at the crossing of the border and the implementation of international supplies of goods;

- create data banks for participants of transnational organized crime;

- involve financial institutions in the implementation of national, regional and international programs for the prevention and counteraction of organized crime;

- provide mutual assistance in the field of criminal justice, extradition and extradition;

- constantly carry out measures aimed at combating money laundering, trafficking, smuggling, trafficking in human beings, international terrorism, piracy, environmental crimes, etc.; 
- intensify activities to detect suspicious banking transactions involving the transfer of money abroad;

- take effective measures and adopt appropriate laws aimed at resolute counteraction to corruption, which promotes the activities of organized criminal groups;

- develop and improve specific training programs for law enforcement personnel, and apply other mechanisms of international cooperation in combating organized crime.

The main objective of international cooperation is to ensure that counteraction to organized crime is adequately secured by the activities of state institutions and coordinated at the interstate level.

\section{CONCLUSIONS}

Expressions of organized crime cause significant damage to the state and its institutions, and in general to its society. The need for in-depth knowledge of this phenomenon is due to the urgent need to reduce the negative effects of its manifestation. In Ukraine the epressions of organized crime also have a significant negative impact, especially in such a difficult time for the country to reform and find new ways to build it. Underestimation of the threats posed by organized crime can have fatal consequences for the whole society.

Ukraine on the way of active counteraction to organized crime, and now implementing and reforming the law enforcement and judicial systems, should maintain their effectiveness in the fight against and fight against crime, create the legal basis for qualitative interaction among themselves in achieving the ultimate goal. One of the priorities of its domestic policy should be the desire to effectively counter organized crime and minimize the negative consequences for society of its activities.

In general, the study of issues of counteraction to organized crime should be carried out in the direction of improving the legal framework for bringing to justice its representatives. Reducing the indicators of manifestations of organized crime in Ukraine indicates that criminal gangs change the tactics of their activities, which greatly complicates their detection.

In order to form an effective system for counteracting of organized crime, scientific development should be carried out, in particular, in order to systematize and to simplify the criminal-law basis of counteraction to organized crime, to make it more precise, avoiding evaluative concepts and opportunities to further ambiguous interpretation in application. 
Investigation of the processes of determination of crime has a very practical significance. In general, in criminological science, the theory of determination and factors that determine the phenomenon of crime contributed to the development of major groups of factors that affect crime: social, economic, legal, organizational and managerial; culturalideological, moral, political, etc. It contributes to an effective further analysis of the state of crime for forming ways of confronting a scientifically sound, rational and calculated outcome. The importance of knowing the determination of crime is conditioned by the need to develop and prevent effective countermeasures and combating this multifaceted phenomenon.

The significance of the socio-economic factors of state development in their influence on the genesis of organized crime can not be overestimated. Organized crime continually holds the heart on the pulse of social and economic life of the country. If you have only the slightest opportunity to use certain circumstances for your own benefit, it will definitely benefit them. A clear, sustainable and systematic legal development of the country's social and economic life, together with effective crime prevention measures, can provide the basis for reducing the negative impact of its activities on the territory of our country.

\section{SUMMARY}

The article is devoted to the problems of counteraction of organized crime in Ukraine. The research of the theoretical and legal foundations of counteraction to crime was conducted, attention was paid to certain aspects of counteraction. On the way of active counteraction to organized crime our state is currently reforming the law enforcement and judicial systems, introducing amendments to the current legislation. The current crime situation in the state indicates the need to improve measures aimed at neutralizing the influence of factors that predetermine the development of organized crime. Among the legal factors of the spread and reproduction of organized crime can be called such as the imperfection of the criminal legal regulation of counteraction to organized crime; internal contradiction and inconsistency of the system of legislation, in particular economic and tax, and the imperfection of the provisions of certain legislative acts regulating crime counteraction. In order to form an effective system for counteracting organized crime, scientific developments should be carried out, in particular, in order to systematize and to simplify the criminal-law basis of counteraction to organized 
crime, to make it more precise, avoiding evaluative concepts and opportunities to further ambiguous interpretation in application.

\section{REFERENCES}

1. Бандурка А.А. Противодействие преступности: теория, практика, проблемы / А.А.Бандурка, Л.М. Давиденко. - Х., 2005. C. 86-87.

2. Закалюк А.П. Курс сучасної української кримінології: теорія і практика: у 3 кн. / Закалюк А.П. - К.: Видавничий дім «Ін Юре», 2007. - Кн. 1. Теоретичні засади та історія української кримінологічної науки. - С. 321.

3. Криминология: учебник для вузов / [Аргунова Ю.Н., Ванюшкин С.В., Ващенко Ю.В. и др.]; под общ. ред. д.ю.н., проф. А.И. Долговой. - [2-е изд., перераб. и доп.] - М.: Изд-во Норма, 2003. С. 377-387.

4. Литвак О.М. Державний вплив на злочинність. Кримінолого правове дослідження / Литвак О.М. - К.: Юрінком Інтер, 2000. - 280 с.

5. Алексеев А.И. Криминологическая профилактика: теория, опыт, проблемы / А.И. Алексеев, Герасимов С.И., Сухарев А.Я. - М.: Изд-во HOPMA, 2001. - $496 \mathrm{c}$.

6. Литвинова Г.П. Профілактика злочинів: управлінський аспект // Нормативно-правові акти та коментарі / Г.П. Литвинова, О.М. Литвинов: метод. видання. - Херсон: Айлант, 2001. - С. 8-18.

7. Голіна В.В. Спеціально-кримінологічне попередження злочинності (теорія і практика): автореф. дис. на здобуття наук. ступеня докт. юрид. наук. / В.В. Голіна.- Х., 1994. - С. 21-23.

8. Проблеми протидії злочинності: підруч. / [Кальман О.Г., Козьяков I.М., Куц В.В., Лизогуб Б.В., Мірошниченко С.С., Подільчак О.М., Толочко А.М., Туркот М.С.]; за ред. проф. О.Г. Кальмана. - К., 2010. - 370 с.

\section{Information about the author: Miniailo N. Ye. \\ Candidate of Juridical Sciences,} Associate Professor at the Department Special-Legal Disciplines of the V. I. Vernadsky Taurida National University 33, Ivana Kudri str., Kyiv, 01042, Ukraine 